\title{
Degradation kinetics of colour, vitamin C and drip loss in frozen broccoli (Brassica oleracea L. ssp. Italica) during storage at isothermal and non-isothermal conditions
}

\author{
Elsa M. Gonçalves ${ }^{a}$, Marta Abreu $^{a}$, Teresa R.S. Brandão ${ }^{b}$, Cristina L.M. Silva ${ }^{b, *}$ \\ ${ }^{a}$ Unidade de Investigação de Tecnologia Alimentar, Instituto Nacional de Recursos Biológicos, Estrada do Paço do Lumiar, \\ 22, 1649-038 Lisboa, Portugal \\ ${ }^{\mathrm{b}}$ Centro de Biotecnologia e Química Fina, Escola Superior de Biotecnologia, Universidade Católica Portuguesa, \\ Rua Dr. António Bernardino de Almeida, 4200-072 Porto, Portugal
}

Keywords:

Broccoli

Freezing

Storage

Quality

Storage life

Modelling

A B S T R A C T

Studies were undertaken on colour CIE $L^{*} a^{*} b^{*}$ values, vitamin C (ascorbic acid) and drip loss alterations of frozen broccoli (Brassica oleracea L. ssp. Italica) stored at isothermal $(-7,-15$, and $-25^{\circ} \mathrm{C}$ ) and non-isothermal (accelerated life testing with step-stress methodology; temperature range from -30 to $-5{ }^{\circ} \mathrm{C}$ ) conditions. The storage temperatures were selected according to conditions that occur in the cold chain.

Frozen storage at all regimes had significant impact on all quality parameters analysed. Significant alterations in broccoli green colour, vitamin C content and drip loss were observed.

Experimental data of $h^{*}$ colour degradation and drip loss (\%) at isothermal conditions and $a^{*} / a_{0}{ }^{*}$ at non-isothermal conditions could be modelled by zero order kinetics. A first order kinetic model was adequate for the remaining quality factors and temperature regimes. The effect of storage temperature on kinetic parameters was successfully described by the Arrhenius equation.

\section{Cinétique de détérioration de la couleur, de la teneur en vitamine $C$ et exsudats du brocoli (Brassica oleracea $L$. ssp. Italica) pendant l'entreposage sous des conditions isothermes et non isothermes}

Mots clés : brocoli ; surgélation ; entreposage ; qualité ; durée de conservation ; modélisation

\footnotetext{
* Corresponding author. Tel.: +351 22 5580058; fax: +351 225090351.

E-mail addresses: elsa.goncalves@inrb.pt (E.M. Gonçalves), marta.abreu@inrb.pt (M. Abreu), tsbrandao@esb.ucp.pt (T.R.S. Brandão), clsilva@esb.ucp.pt (C.L.M. Silva).
} 


\section{Introduction}

Broccoli (Brassica oleracea L. ssp. Italica) is a cruciferous vegetable rich in health-promoting compounds, such as fibre, vitamin $\mathrm{C}$, glucosinolate and flavonoid, and selenium. These compounds have gained attention because of their role in the prevention of cancer and cardiovascular diseases (Finley et al., 2000; Keck and Finley, 2004). After harvest, broccoli is a highly perishable vegetable that rapidly (in few days) loses its bright green colour. Lowering the temperature (till $0-4{ }^{\circ} \mathrm{C}$ ) and increasing the relative humidity (till 95-100\%) extent the vegetable shelf-life for one to two weeks (Jones et al., 2006).

Freezing of vegetables is one of the most common processes for quality preservation, because at those low temperatures deteriorative reactions are reduced to minimal rates and microorganism's growth is restricted. However, the quality of frozen vegetable is highly dependent on the characteristics of the raw food (Simandjuntak et al., 1996), environmental conditions to which the vegetable is exposed after being subjected to the freezing process (Alvarez and Canet, 2000; Sahari et al., 2004), pre-freezing operations such as blanching (Jaworska et al., 2008; Olivera et al., 2008), and the freezing process itself.

Inevitably, the freezing process and the frozen storage have negative impacts on food quality. The main physical changes that occur during frozen storage are moisture migration and ice recrystallization (Van Buggenhout et al., 2006b). Both phenomena are related to the stability of products' frozen water, which affects the vegetable texture and loss of nutrients and weight if thawing drip loss takes place (Pukszta and Palich, 2007). Moreover, chemical changes in frozen vegetables are related with onset of off-odour and off-flavours (especially if vegetables were not blanched; Nielsen et al., 2003), pigment and colour degradation (Lisiewska et al., 2004) and chemical oxidation (e.g. of vitamin C; Serpen et al., 2007).

The (EU Directive 89/108) recommends that storage temperature must be stable and maintained below $-18^{\circ} \mathrm{C}$ for a storage period between 6 and 24 months. However, quality of frozen food is highly dependent on storage temperature, with lower temperatures leading to longer shelf-life. Quality deterioration is emphasised by storage temperatures variations that often occur in the frozen chain, and that are consequences of temporary breakdown of facilities or equipment, improper response of temperature controlling devices, excessive loads during freezing or unacceptable handling (Taoukis et al., 1991). The knowledge of the exact influence of storage temperature for each frozen vegetable would help to determine adequate conditions to enhance quality and determine its shelf-life.

In general, microbiological criteria are of primary importance to established food products' shelf-life, specially for the highly perishable ones (Corbo et al., 2006). However, the frozen vegetables shelf-life is normally established by sensory evaluation (IIR, 1986). Since results are based on subjective decisions, Giannakourou and Taoukis (2003), Reid et al. (2003) and Martins and Silva (2004a) proposed the use of objective measurements, such as colour and texture, and content of nutritional compounds, e.g. vitamin $\mathrm{C}$, that can be considered an important back-up to sensory methods. Even so, no well- defined criteria have been until now established and it is important to identify which factor is of utmost importance in the frozen vegetable shelf-life definition.

Normally, studies to assess the impact of frozen storage on products' stability require sampling throughout long-term periods. For this reason, different methodologies have been developed to accelerate shelf-life testing (ALT), which, in general terms, refers to any method that is capable of evaluating product stability, based on data that are obtained in a significantly shorter period than the actual shelf-life of the product. Authors like Martins and Silva (2004b), Hough et al. (2006), Corradini and Peleg (2007) and Martins et al. (2008) used accelerate shelf-life testing and discussed different modelling approaches and how they can be used in shelf-life predictions. Several of these models were applied to evaluate/predict quality and shelf-life of a variety of food products during frozen storage: potatoes (Alvarez and Canet, 1998), green beans (Martins et al., 2005), watercress (Cruz et al., 2009), dough and bread (Phimolsiripol et al., 2008), meat (Berry and Leddy, 1989) and fish and shrimp (Koutsoumanis et al., 2002; Tsironi et al., 2009).

Therefore, the objectives of this work were to study the effect of the freezing process (with a pre-blanching step) and frozen storage on some quality factors of broccoli. Kinetic models were fitted to data obtained under isothermal and non-isothermal frozen storage, using accelerated life testing methodology. Determination of frozen broccoli shelf-life was also a target.

\section{Materials and methods}

\subsection{Raw material}

Fresh broccoli (Brassica oleracea L. spp Italica cv. Marathon) was obtained directly from cultivated area in Torres Vedras, Portugal. Leaves were removed and broccoli inflorescences were divided into florets of about $5 \mathrm{~cm}$ diameter, cut $2 \mathrm{~cm}$ below the lowest ramification.

\subsection{Pre-blanching and freezing process}

For blanching treatments, samples were immersed in a thermostatic water bath $\left( \pm 1^{\circ} \mathrm{C}\right)$ of $50 \mathrm{~L}$ capacity. The blanching conditions (i.e. $70{ }^{\circ} \mathrm{C}$ for $6.5 \mathrm{~min}$ ) were the ones optimized by Gonçalves et al. (2009b). The temperatures of the water and samples were monitored throughout the thermal treatment, using thermocouples (type $\mathrm{T}$ thin thermocouple, $1.2 \mathrm{~mm}$ diameter, embedded in a stainless steel hypodermic needle, Ellab, Denmark, with an accuracy of $\pm 2{ }^{\circ} \mathrm{C}$ ). After blanching, samples were cooled into an ice water bath for $2 \mathrm{~min}$; excess of moisture was removed before any further analysis and/or process.

Blanched samples were frozen in a vertical forced air freezer (Refriger, Electro-Refrigeração, Portugal) at $-40{ }^{\circ} \mathrm{C}$ (average value), until the temperature of the centre of samples reached $-35^{\circ} \mathrm{C}$. Temperature was recorded with thermocouples (type $\mathrm{T}$ thin thermocouple, $1.2 \mathrm{~mm}$ diameter, embedded in a stainless steel hypodermic needle, Ellab, Denmark, with an accuracy of $\pm 2{ }^{\circ} \mathrm{C}$ ). Frozen broccoli ( $\sim 500 \mathrm{~g}$ each) was 
immediately packed into polyethylene bags $(22 \times 35 \mathrm{~cm})$ and sealed.

\subsection{Frozen storage regimes}

After freezing, two frozen storage regimes (I and II) were considered.

\subsubsection{Regime I}

Corresponds to isothermal frozen storage conditions at -7 , -15 and $-25^{\circ}\left( \pm 1^{\circ} \mathrm{C}\right)$. Frozen samples were distributed into three laboratory freezers (Fitotherm, S550 BT) at the constant temperatures established. Samples were removed at heuristic time intervals (i.e. sampling tended to be equally spaced in the time scale), over a period of 121 days.

\subsubsection{Regime II}

Corresponds to non-isothermal frozen storage conditions, considering accelerated life testing (ALT) with step-stress methodology (i.e. consecutive increases in temperature, by step levels). Samples were stored in sequence at $-30^{\circ} \mathrm{C}$ (for 21 days), $-20^{\circ} \mathrm{C}$ (for 16 days), $-10^{\circ} \mathrm{C}$ (for 11 days) and $-5^{\circ} \mathrm{C}$ (for 9 days), totalling 57 days. Samples were removed at heuristic time intervals (i.e. sampling tended to be equally spaced in the time scale).

Air and product temperatures were monitored using type $\mathrm{T}$ thermocouples connected to an acquisition data system with software LabView 8.2 (National Instruments) and an OMBDAQ-56 multi function data acquisition module (Omega Engineering, Stamford, CT).

Before any further analysis, samples were thawed at $4{ }^{\circ} \mathrm{C}$ for $15 \mathrm{~h}$ in a refrigerator with air temperature control. This period of time was enough to reach the same temperature value of all samples $\left(4^{\circ} \mathrm{C}\right)$, regardless the different temperatures used in the frozen regimes.

\subsection{Quality analysis}

\subsubsection{Peroxidase enzyme}

Peroxidase (POD) activity was measured as the change in absorbance at $420 \mathrm{~nm}$ using guaiacol and $\mathrm{H}_{2} \mathrm{O}_{2}$ as substrates, based on a modified method of Bifani et al. (2002) as described in Gonçalves et al. (2009b). Raw, blanched and frozen (prior to the frozen storage and at the last day of frozen storage) samples were analysed in triplicate.

\subsubsection{Colour evaluation}

For colour determinations, $30 \mathrm{~g}$ of broccoli were triturated and analysed using a tristimulus colorimeter (Colorgard System/05 Gardner port size). The colorimeter was calibrated against standard white and black tiles. Measurements were performed in the CIE $L^{*} a^{*} b^{*}$ system, using an illuminate $C$. Lightness value, $L^{*}$, indicates how dark/light the sample is (varying from 0-black to 100 -white), $a^{*}$ is a measure of greenness/redness (varying from -60 to +60 ), and $b^{*}$ is the grade of blueness/yellowness (also varying from -60 to +60 ). To describe the colour behaviour of broccoli during frozen storage, the normalized $\left(a^{*} / a_{0}^{*}\right)$ value and the hue angle, $h^{*}\left(0-360^{\circ}\right)$ (obtained by $\tan ^{-1} b^{*} / a^{*}$, expressing the characteristic/dominant colour), were used. Data was obtained from 20 measurements on each sample.

\subsubsection{Vitamin C}

In order to determine vitamin $\mathrm{C}$ (ascorbic acid) content, a modified titrimetric AOAC method (1984) was used. $200 \mathrm{~g}$ of each sample were blended with an equal weight of metaphosphotic acid (6\%) using a Waring commercial blender (Dynamics Corporation, CT, USA). $20 \mathrm{~g}$ of the macerate was added to $100 \mathrm{ml}$ of metaphosphotic acid (3\%) and filtered through Whatman $n^{\circ} 42$ filter paper. A filtered sample of $10 \mathrm{ml}$ was titrated with 2,6-dichlorophenolindophenol until persistent pink colour was observed. Three independent extractions were performed per sample and results were expressed as mg ascorbic acid per $100 \mathrm{~g}$ of broccoli samples.

\subsubsection{Drip loss}

Frozen samples were laid over a weighted absorbent paper and let to thaw at $4{ }^{\circ} \mathrm{C}$ (Agnelli and Mascheroni, 2002). Drip loss (DL) was then evaluated by periodically weighting the absorbent paper until a constant value was reached:

$\mathrm{DL}(\%)=\frac{\left(\mathrm{W}_{\mathrm{t}}-\mathrm{W}_{0}\right)}{\mathrm{W}_{\mathrm{s}}} \times 100$

where $W_{0}$ is the weight of the dry absorbent paper $(g), W_{t}$ the weight of the wet absorbent paper at time $t(g)$ and $W_{S}$ the weight of the frozen sample (g). A Metter AT 100 analytical balance with metering precision of $0.00001 \mathrm{~g}$ was used. Measurements were made in triplicate per sample.

\subsection{Modelling procedures}

\subsubsection{The models}

Under isothermal frozen conditions, kinetics of quality changes may be described by a zero or first order kinetic models, Eqs. (2) and (3) respectively, depending on the parameter considered.

$C=C_{0}-k_{0(T)^{t}}$

$\frac{C}{C_{0}}=e^{-k_{1(T)^{t}}}$

where $C$ is the measured quality factor, $t$ is the storage time and $k$ the reaction rate (the subscripts 0 and 1 correspond to zero and first order $k$ values, respectively).

The dependence of the reaction rate on temperature is commonly described by an Arrhenius behaviour:

$k=k_{\text {ref }} \exp \left[-\frac{E_{a}}{R}\left(\frac{1}{T}-\frac{1}{T_{\text {ref }}}\right)\right]$

where $k_{\text {ref }}$ and $E_{a}$ are model parameters, the kinetic rate at a finite reference temperature $\left(T_{\text {ref }}\right)$ and the activation energy, respectively; $R$ is the universal gas constant.

A global model that includes the temperature effect can be obtained by merging Eqs. (2) and (4) or (3) and (4), thus giving:

$C=C_{0}-\left(k_{\text {ref }} \exp \left(-\frac{E_{a}}{R}\left(\frac{1}{T}-\frac{1}{T_{\text {ref }}}\right)\right) t\right)$ 
$C=C_{0} \exp \left(-k_{\text {ref }} \exp \left(-\frac{E_{a}}{R}\left(\frac{1}{T}-\frac{1}{T_{\text {ref }}}\right)\right) t\right)$

Under non-isothermal conditions, and if the variation of temperature with time is known $(T(t))$, the previous equations integrate to:

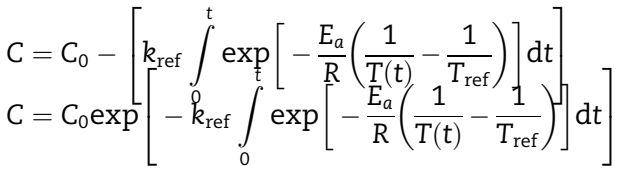

\subsubsection{Data analysis}

For isothermal conditions, Eqs. (5) and (6) were fitted to experimental data using Statistica ${ }^{\odot} 8.0$ (2007), performing a global non-linear regression analysis (quality factor data versus time, at all temperatures) (Lund, 1983; Arabshahi and Lund, 1985).

For non-isothermal conditions, Eq. (7) or (8) were fitted to experimental data. The regression analysis procedures and calculations were performed in programs specially written in FORTRAN 77 language (Fortran 5.1, Microsoft Corporation ${ }^{\circledR}$, 1990). The simplex algorithm was used to minimise the sum of the squares of the residuals (Nelder and Mead, 1965).

The reference temperature assumed was $-15{ }^{\circ} \mathrm{C}$ in all cases (i.e. the average value of the experimental range considered) aiming at improving parameter estimation.

Parameters' precision was evaluated by confidence intervals at $95 \%$, and the quality of the regression was assessed by the coefficient of determination $\left(R^{2}\right)$, and randomness and normality of residuals (Weemaes et al., 1999), thus testing model adequacy.

An analysis of variance (factorial ANOVA with replication) was also performed to evaluate storage time-temperature effects on quality parameters. Pearson correlation coefficients were also calculated to assess correlations between quality measurements.

\section{Results and discussion}

Pre-blanching inactivated approximately $90 \%$ of initial POD activity $\left(712.1 \pm 57.3 \mathrm{Ug}^{-1}\right)$. No peroxidase regeneration was detected during the storage period at different temperature regimes. Therefore, enzymatic activity should not be considered responsible for changes that occurred throughout storage, such as colour or vitamin C (ascorbic acid).

\subsection{Colour changes}

Broccoli colour is the characteristic with most influence on consumer choice. Chlorophyll pigments are responsible for the green colour of many vegetables, namely broccoli. Colour alterations during frozen storage are attributed to the fade of the vivid green colour of chlorophyll to an olive brown, characteristic of pheophytin (Martins and Silva, 2002). The blanched/ frozen broccoli (the reference sample before frozen storage) exhibited a green colour, corresponding to the following average values of the colour coordinates: $L^{*}=22.04 \pm 1.91$, $a^{*}=-17.41 \pm 0.75, b^{*}=15.97 \pm 1.13$ and $h^{*}=137.95 \pm 3.91$.

\subsubsection{Isothermal storage conditions}

During the isothermal frozen storage at the lowest temperatures $\left(-25\right.$ and $\left.-15^{\circ} \mathrm{C}\right)$, the $L^{*}$ value showed a random pattern behaviour around its initial value. However, at $-7^{\circ} \mathrm{C}$, broccoli became lighter and $L^{*}$ value increased $53 \%$ until the last day of storage (data not shown). The normalized $a^{*}\left(a^{*} / a_{0}{ }^{*}\right)$ and $h^{*}$ values (Fig. $1 \mathrm{a}$ and $\mathrm{b}$, respectively) decreased significantly $(P \leq 0.05)$ with the increase of time and temperature of storage, reflecting a change in broccoli green colour. An identical behaviour was also reported by Martins and Silva (2002) and Gonçalves et al. (2009a) in green beans and watercress, respectively. No significantly changes were observed in $b^{*}$ values for the three storage temperatures. However, at $-7^{\circ} \mathrm{C}$ a slight alteration was observed; broccoli became more yellow (13\% of variation; data not shown).

Experimental results of broccoli $a^{*} / a_{0}{ }^{*}$ and $h^{*}$ colour parameter degradation were satisfactorily described by an Arrhenius first and zero order kinetic model, respectively. Fig. 1 ( $a$ and $b$ ) also includes the model fit obtained by a one-step regression analysis (i.e. global fit of data at all temperatures). In all cases normality and randomness of residuals were verified, thus proving model adequacy. In spite of the high variability of broccoli colour data, the coefficient of determination, $R^{2}$, was satisfactorily high ( 0.85 for both situations). The kinetic parameters are given in Table 1 . The activation energies found by Martins and Silva (2002) for green beans and Gonçalves et al. (2009a) for watercress were substantially higher (103 and $174 \mathrm{~kJ} \mathrm{~mol}^{-1}$ for $a_{\mathrm{H}}$ and $h^{*}$ colour parameters, respectively).

\subsubsection{Non-isothermal storage conditions}

At the end of storage under non-isothermal conditions (57 days), broccoli colour parameters $a^{*} / a_{0}{ }^{*}$ and $h^{*}$ decreased 30 and $5 \%$ respectively (Fig. $1 \mathrm{c}$ and d). The degree of greenness was more affected than the degree of tonality. These alterations were lower than the ones observed under isothermal storage at $-7{ }^{\circ} \mathrm{C}$ for the same period of time $\left(a^{*} / a_{0}{ }^{*}\right.$ degraded $47 \%$ and $\left.h^{*} 13 \%\right)$, but were higher than the ones obtained at $-25{ }^{\circ} \mathrm{C}$ ( $a^{*} / a_{0}{ }^{*}$ degraded $17 \%$, and $h^{*} 3 \%$ ).

Under non-isothermal conditions, first and zero-order kinetic models Eqs. (7) and (8) were adequate in describing $a^{*} / a_{0}{ }^{*}$ and $h^{*}$ changes, respectively (model fits are included in Fig. $1 \mathrm{c}$ and d; parameters estimates are in Table 1). The coefficients of determination were 0.40 and 0.44 , respectively for $a^{*} / a_{0}{ }^{*}$ and $h^{*}$, revealing a great dispersion of experimental data. Nevertheless, analyses proved residuals randomness and normality, and consequently there is statistically supported evidence that models were adequate in data fitting.

The kinetics of broccoli colour alterations under nonisothermal conditions presented considerably lower activation energy values, when compared to isothermal conditions. The values were also lower than the ones reported by Martins et al. (2005) for green beans colour parameters (e.g. for $a_{H}$ parameter, $111.9 \mathrm{~kJ} \mathrm{~mol}^{-1}$ ).

\subsection{Vitamin C losses}

Vitamin C is a water soluble vitamin that is widely considered as an appropriate marker for monitoring quality changes 

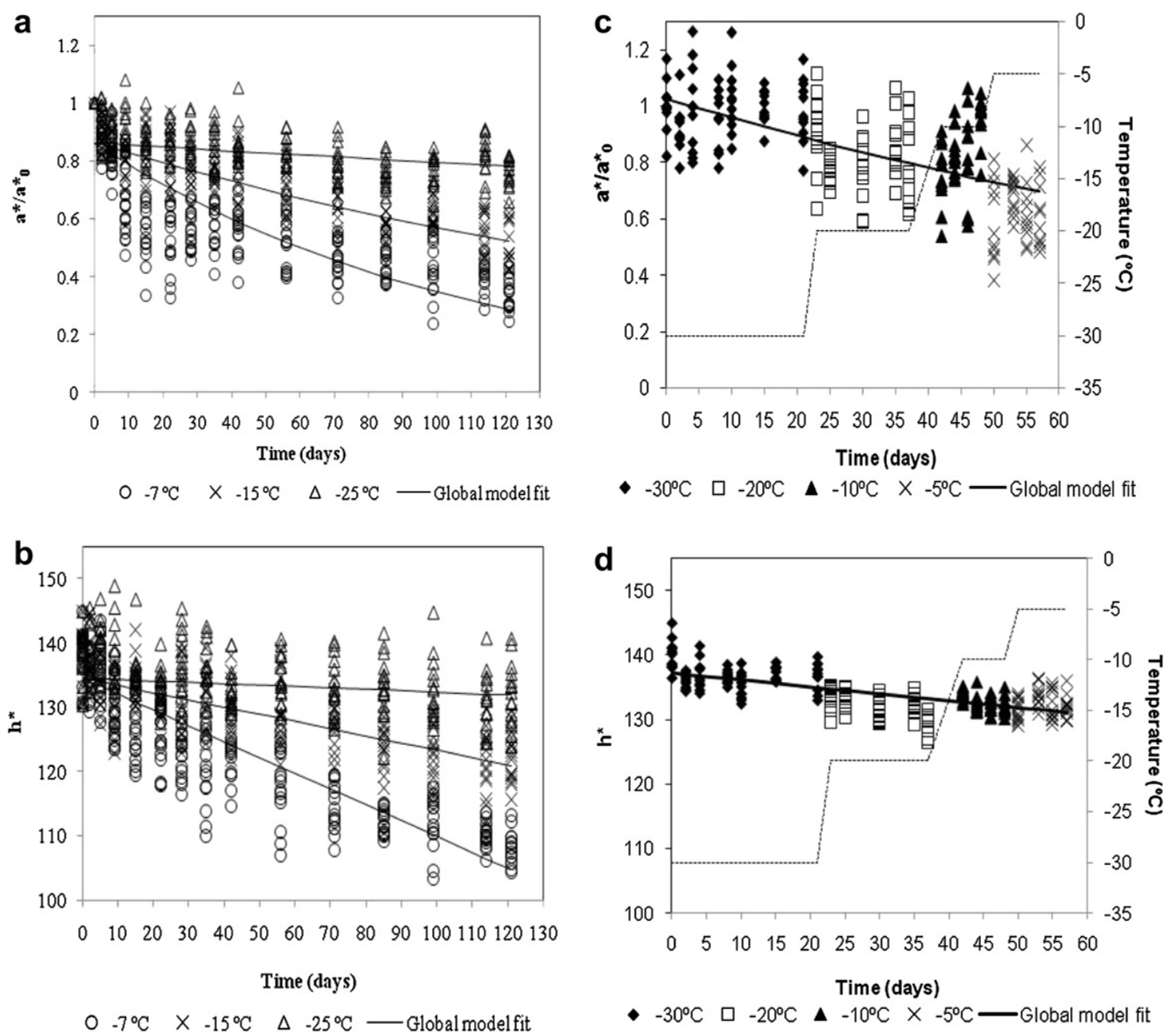

Fig. 1 - Broccoli colour degradation during frozen storage: under isothermal conditions (a) $a^{*} / a_{0}{ }^{*}$ and $(b)$ hue $\left(h^{*}\right)$ parameters; under non-isothermal conditions (c) $a^{*} / a_{0}{ }^{*}$ and (d) hue $\left(h^{*}\right)$ parameters (dotted lines indicate temperature history of regime II).

during processing, storage and at the end point of the frozen chain. This is a consequence of its concentration change due to irreversible oxidation mechanisms that are enhanced by temperature abuses (Serpen et al., 2007).
Even after the blanching and freezing operations, broccoli (before frozen storage; the reference sample) presented a vitamin C (ascorbic acid) content of $36.07 \pm 0.98 \mathrm{mg} / 100 \mathrm{~g}$, which is higher than the values reported for other green fresh

Table 1 - Kinetic parameters, and corresponding confidence intervals at $95 \%$, of broccoli colour parameters, vitamin C (ascorbic acid) content and drip loss due to isothermal and non-isothermal frozen storage.

\begin{tabular}{|c|c|c|c|c|c|c|}
\hline \multirow[t]{2}{*}{ Frozen storage } & \multicolumn{2}{|l|}{ Quality factor } & \multirow[t]{2}{*}{ Model } & \multicolumn{3}{|c|}{ Kinetic parameters } \\
\hline & & & & $C_{0}$ & $\mathrm{k}_{-15^{\circ} \mathrm{C}} \times 10^{3}\left(\right.$ days $\left.^{-1}\right)$ & $\begin{array}{c}E_{a} \\
\left(\mathrm{~kJ} \mathrm{~mol}^{-1}\right)\end{array}$ \\
\hline \multirow[t]{4}{*}{ Isothermal } & Colour & $a^{*} / a_{0}^{*}$ & $k_{1(T)}$ & $0.87 \pm 0.012$ & $4.35 \pm 0.38$ & $53.58 \pm 5.58$ \\
\hline & & $h^{*}$ & $k_{0(T)}$ & $134.69 \pm 0.52$ & $0.90 \pm 0.091$ & $58.96 \pm 6.78$ \\
\hline & Vitamin C (ascorbic acid) & (mg/100g) & $k_{1(T)}$ & $32.91 \pm 0.70$ & $6.80 \pm 0.69$ & $60.24 \pm 7.20$ \\
\hline & Drip loss & (\%) & $k_{0(T)}$ & $11.26 \pm 0.24$ & $42.66 \pm 4.73$ & $42.31 \pm 6.89$ \\
\hline \multirow[t]{4}{*}{ Non-isothermal } & Colour & $a^{*} / a_{0}^{*}$ & $k_{1(T)}$ & 1.03 & 6.91 & 0.017 \\
\hline & & $h^{*}$ & $k_{0(T)}$ & 137.23 & 0.81 & 0.11 \\
\hline & Vitamin C (ascorbic acid) & $(\mathrm{mg} / 100 \mathrm{~g})$ & $k_{1(T)}$ & 34.73 & 7.55 & 0.0039 \\
\hline & Drip loss & (\%) & $k_{1(T)}$ & 12.15 & 366.80 & 0.0047 \\
\hline
\end{tabular}

The subscripts 0 and 1 correspond to zero and first order kinetics, respectively. 
vegetables (green beans 25-10 mg/100 g; spinach 31-22 mg/ 100 g; peas $26.5 \mathrm{mg} / 100 \mathrm{~g}$ Serpen et al., 2007; Martins and Silva, 2002). Similar (34 mg/100 g) and higher (60 mg/100 g) frozen broccoli vitamin C contents were reported by Sikora et al. (2008) and Gębczyński and Lisiewska (2006), respectively.

\subsubsection{Isothermal storage conditions}

The effect of frozen storage at different temperatures on vitamin $\mathrm{C}$ degradation is in Fig. 2a. After 121 days of isothermal storage, the vitamin C content significantly decreased c.a. $80 \%, 60 \%$ and $29 \%$, respectively at $-7,-15$ and $-25^{\circ} \mathrm{C}$. The major loss of vitamin $\mathrm{C}$ occurred during the first 55 days of storage. Similar results were found by Giannakourou and Taoukis (2003) for frozen green beans, spinach, green peas and okra, and by Sahari et al. (2004) for strawberries. Gębczyński and Lisiewska (2006) observed a significantly better vitamin $\mathrm{C}$ retention in broccoli stored at $-30^{\circ} \mathrm{C}$.

An Arrhenius first order kinetic model Eq. (6) satisfactorily fitted the experimental data of vitamin $\mathrm{C}$ degradation under frozen storage (global fit of data obtained at all
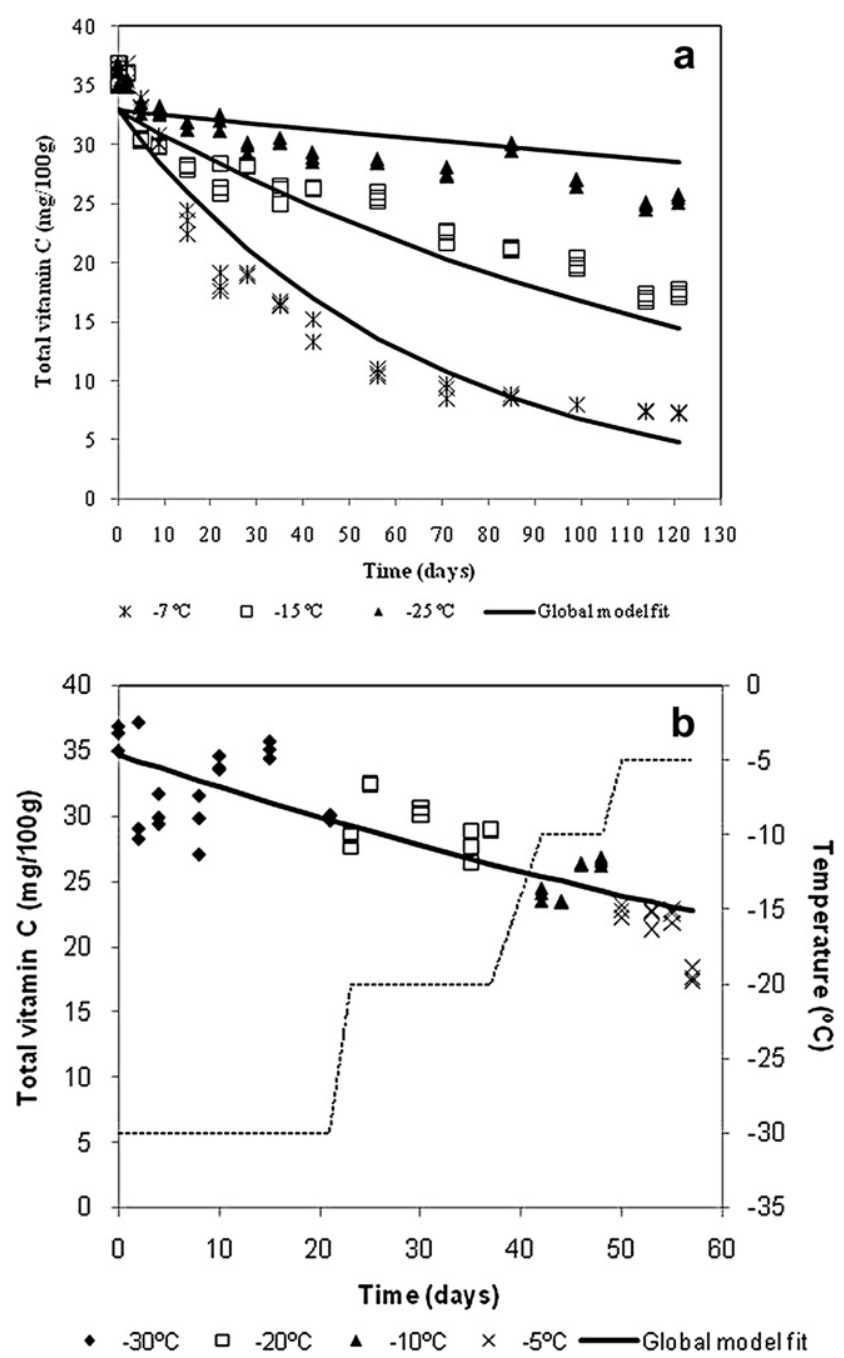

Fig. 2 - Broccoli vitamin C (ascorbic acid) content degradation during frozen storage: (a) under isothermal conditions (b) under non-isothermal conditions (dotted line indicates temperature history of regime II). temperatures in Fig. 2a; kinetic parameters included in Table $\left.1 ; R^{2}=0.96\right)$.

The estimated activation energy for vitamin C degradation of frozen broccoli was higher than the ones obtained by Martins and Silva (2003) for green beans $\left(42 \mathrm{~kJ} \mathrm{~mol}^{-1}\right.$ ) and by Gonçalves et al. (2009a) for watercress $\left(25 \mathrm{~kJ} \mathrm{~mol}^{-1}\right)$. However, the values reported by Giannakourou and Taoukis (2003) for green peas, green beans, spinach and okra ranged from 98 to $112 \mathrm{~kJ} \mathrm{~mol}^{-1}$.

Shelf-life of frozen broccoli was established taking into account the half-life of vitamin $C$ (ascorbic acid) content (Serpen et al., 2007). Predictions based on Eq. (6) and parameters in Table 1 allowed concluding that the shelf-life of preblanched frozen broccoli can achieve 125 days at $-18^{\circ} \mathrm{C}$.

\subsubsection{Non-isothermal storage conditions}

Fig. $2 \mathrm{~b}$ shows the changes in broccoli vitamin $\mathrm{C}$ (ascorbic acid) through the frozen storage at non-isothermal conditions. At the end of the storage period considered, broccoli losses c.a $51 \%$ of its vitamin C content. Therefore, and using Serpen et al. (2007) criterion (reduction of $50 \%$ of vitamin C content), broccoli reached its shelf-life. Based on the same principle, Giannakourou and Taoukis (2003) reported shorten shelf-life for frozen green peas and spinach (25 and 5 days, respectively) exposed to changeable temperatures. Frozen raspberry stored for 24 days under temperature fluctuations decreased c.a $20 \%$ of its initial vitamin C content (Sousa et al., 2005). However, Cruz et al. (2009) and Gormley et al. (2002) did not notice variation in vitamin $C$ content in watercress and strawberries respectively, submitted to time-varying temperature conditions.

An Arrhenius first order kinetic model Eq. (8) was also satisfactorily fitted to experimental data for the degradation of vitamin C content (see Fig. 2b). The quality of the model fit was assessed by analyses to the residuals. The value of $R^{2}$ was 0.67 . Estimated kinetic parameters are included in Table 1. Martins and Silva (2004b) for green beans reported higher activation energy values $\left(41.97 \mathrm{~kJ} \mathrm{~mol}^{-1}\right)$.

\subsection{Drip loss}

During frozen storage, ice crystal recrystallization may cause loss of cell turgor following in a leakage of cell content and loss of cell water holding capacity, resulting in thawing drip loss. A consequence is a direct texture damaged and changes in the sensory crispness or juiciness of vegetable tissue and a discard in a significant amount of water-soluble nutrients (Simandjuntak et al., 1996; Van Buggenhout et al., 2006b). Therefore, the amount of the thawing drip loss is an indicator of reversibility effect of the frozen process on the tissue, cells and fibres of vegetables (Pukszta and Palich, 2007).

\subsubsection{Isothermal storage conditions}

Fig. 3a shows the effect of the three different storage temperatures on frozen broccoli drip loss. As storage time and temperature increase, a significantly increase in drip loss was observed. During storage at $-7,-15$ and $-25{ }^{\circ} \mathrm{C}$, drip loss increased approximately $88 \%, 43 \%$ and $12 \%$, respectively, at the end of the storage period. It was the quality parameter mostly affected by the temperature of storage. The increase in drip loss is suggestive of a mechanical disruption of the cell 

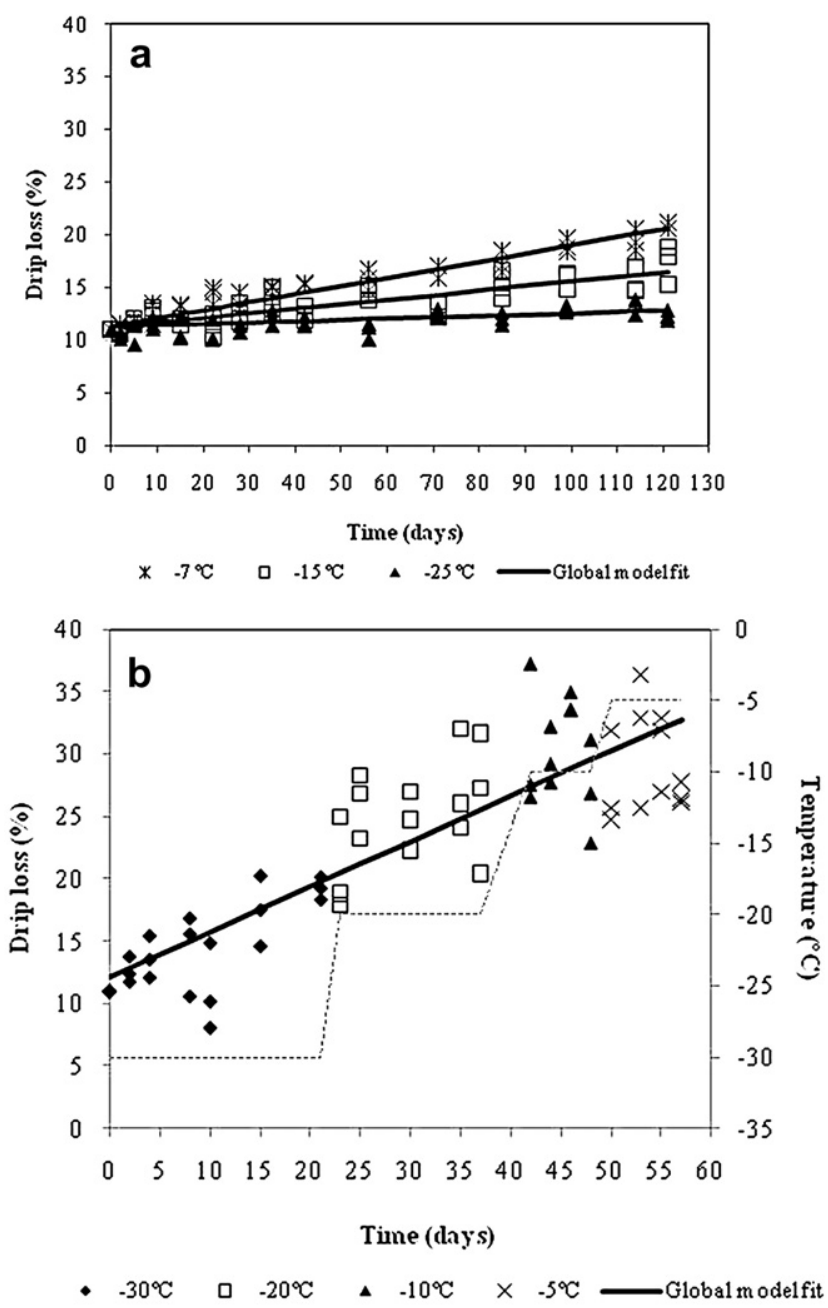

Fig. 3 - Broccoli thawing drip loss (\%) during frozen storage: (a) under isothermal conditions; (b) under nonisothermal conditions (dotted line indicates temperature history of regime II).

wall promoted by changes in size, number and form of ice crystals (Hagiwara et al., 2002). Other authors have also reported the increase in drip loss with frozen storage time in different fruits and vegetables (Van Buggenhout et al., 2006a, O'Leary et al., 2000). However, for Redmond et al. (2004) frozen storage for up to 12 months had no statistically significant effect on the centrifugal drip loss from steamed freezechilling carrots and green beans. This quality parameter is widely used to evaluate different freezing methods on foods quality, or to assess the suitability of different vegetables cultivars to frozen storage (Fúster et al., 1994; Agnelli and Mascheroni, 2002; Lefever et al., 2004).

A zero order kinetic model with Arrhenius temperature dependence Eq. (5) fitted well the experimental data for drip loss (Fig. 3a). The activation energy and the reaction rate at a reference temperature of $-15{ }^{\circ} \mathrm{C}$, and corresponding $95 \%$ confidence intervals, are reported in Table 1 . The quality of the model fit was assessed by analysis to the residuals (i.e. normality and randomness were confirmed). The value of regression coefficient $\left(R^{2}\right)$ was 0.94 . The $E_{a}$ estimated value was lower than those obtained for the other quality parameters analysed (colour and vitamin $\mathrm{C}$ ). No published data on drip loss kinetics have been found in the literature.

In addition, drip loss was negatively correlated with colour $a^{*} / a_{0}{ }^{*}$ parameter and vitamin $C$ (ascorbic acid). The correlation coefficients of Pearson were 0.92 and 0.60 , respectively.

\subsubsection{Non-isothermal storage conditions}

Under non-isothermal conditions, drip loss occurred at a significant faster rate when compared to isothermal regimes (Fig. 3b). At the end of storage (57 days), broccoli drip loss suffered an alteration of approximately $143.5 \%$. Comparing this result with the worse scenario obtained under isothermal conditions (drip loss of $87 \%$ at the highest temperature of $-7{ }^{\circ} \mathrm{C}$ ) it can be concluded that non-isothermal storage had a great impact. Pukszta and Palich (2007) observed also a considerable increase in the amount of thawing drip loss (c.a $79 \%$ ) for strawberries stored under time-varying temperature conditions.

The broccoli drip loss followed a first order reaction kinetics ((8); experimental data and model fits in Fig. 3b; estimated parameters in Table 1), with a coefficient of determination of 0.75 .

\section{Conclusion}

Frozen storage of broccoli under isothermal and nonisothermal conditions affected the colour, vitamin C (ascorbic acid) content and thawing drip loss. The accelerated life test method used in this work was a good tool for studying kinetics of quality changes.

Drip loss was the most sensitive quality factor to frozen storage under isothermal and non-isothermal condition. Appling a threshold of $50 \%$ vitamin C loss, as recommended, the shelf-life of frozen broccoli stored under a constant temperature of $-18{ }^{\circ} \mathrm{C}$ was about 4 months.

To minimise oxidation processes in broccoli, alterations in colour and water migration phenomena, fluctuations of temperature throughout frozen storage and distribution should be controlled.

\section{Acknowledgements}

The author T.R.S. Brandão acknowledges financial support to Fundação para a Ciência e a Tecnologia (Portugal), via a PostDoctoral fellowship (SFRH/BPD/11580/2002).

\section{R E F E R E N C E S}

Agnelli, M.E., Mascheroni, R.H., 2002. Quality evaluation of foodstuffs frozen in a cryomechanical freezer. J. Food Eng. 52, 257-263.

Alvarez, M.D., Canet, W., 1998. Effect of temperature fluctuations during frozen storage on the quality of potato tissue (cv. Monalisa). Z. Lebensm. Unters. Forsh. A 206, 52-57. 
Alvarez, M.D., Canet, W., 2000. Principal component analysis to study the effect of temperature fluctuations during storage of frozen potato. Eur. Food Res. Technol. 211, 415-421.

AOAC official methods of analysis. 1984. Vitamin C (ascorbic acid) in vitamin preparations and juices, 2,6-dichloroindophenol titrimetric Method.

Arabshahi, A., Lund, D., 1985. Considerations in calculating kinetic parameters from experimental data. J. Food Proc. Eng. 7, 239-251.

Berry, B.W., Leddy, K.F., 1989. Effect of freezing rate, frozen storage temperature and storage time on tenderness values of beef patties. J. Food Sci. 54, 291-296.

Bifani, V., Inostroza, J., Cabezas, M.J., Ihl, M., 2002. Determinacion de parametros cinéticos de peroxidasa y clorofila en judias verdes (Phaseolus vulgaris cv. Win) y estabilidad del producto congelado. Rev. de Quimica Teorica y Aplicada LIX, 57-64.

Corbo, M.R., Del Nobile, M.A., Sinigaglia, M., 2006. A novel approach for calculating shelf life of minimally processed vegetables. Int. J. Food Microbiol. 106, 69-73.

Corradini, M.G., Peleg, M., 2007. Shelf-life estimation from accelerated storage data. Trends Food Sci. Technol. 18, 37-47.

Cruz, R.M.S., Vieira, M.C., Silva, C.L.M., 2009. Effect of cold chain temperature abuses on the quality of frozen watercress (Nasturtium officinale R. Br.). J. Food Eng. 94, 90-97.

EU Directive 89/108 on the Approximation of the laws of the Member States relating to Quick-Frozen Foodstuffs for Human Consumption (Directive du Conseil du 21 décembre 1988 relative au rapprochement des legislations des Etats members concernant les aliments surgelés destines à l'alimentation humaine (89/109/CEE)).

Fúster, C., Préstamo, G., Cano, M.P., 1994. Drip loss, peroxidase and sensory changes in kiwi fruit slices during frozen storage. J. Sci. Food Agric. 64, 23-29.

Finley, J.W., Davis, C.D., Feng, Y., 2000. Selenium from high selenium broccoli protects rats from colon cancer. J. Nutr. 130, 2384-2389.

Gębczyński, P., Lisiewska, Z., 2006. Comparison of the level of selected antioxidative compounds in frozen broccoli produced using traditional and modified methods. Innovative Food Sci. Emerg. Technol. 7, 239-245.

Giannakourou, M.C., Taoukis, P.S., 2003. Kinetics modelling of vitamin $C$ loss in frozen green vegetables under variable storage conditions. Food Chem. 83, 33-41.

Gonçalves, E.M., Cruz, R.M.S., Abreu, M., Brandão, T.R.S., Silva, C. L.M., 2009a. Biochemical and colour changes of watercress (Nasturtium offinale R. Br.) during freezing and frozen storage. J. Food Eng. 93, 32-39. 2009.

Gonçalves, E.M., Pinheiro, J., Alegria, C., Abreu, M., Brandão, T.R.S., Silva, C.L.M., 2009b. Degradation kinetics of peroxidase enzyme, phenolic content, and physical and sensorial characteristics in broccoli (Brassica oleracea L. ssp. Italica) during blanching. J. Agric. Food Chem. 57, 5370-5375.

Gormley, R., Walshe, T., Hussey, K., Butler, F., 2002. The effect of fluctuating vs. constant frozen storage temperature regimes on some quality parameters of selected food products. Lebensm. Wiss. Technol. 35, 190-200.

Hagiwara, T., Wang, H., Suzuki, T., Takai, 2002. R. Fractal analysis of ice crystals in frozen food. J. Agric. Food Chem. 50, 3085-3089.

Hough, G., Garitta, L., Gómez, G., 2006. Sensory shelf-life predictions by survival analysis accelerated storage models. Food Qual. Pref 17, 468-473.

International Institute of Refrigeration, 1986. IIR. In: Recommendations for the Processing and Handling of Frozen Foods Paris.

Jaworska, G., Bernaś, E., Cichoń, Z., Possinger, P., 2008. Establishing the optimal period of storage for frozen Agaricus bisporus, depending on the preliminary processing applied. Int. J. Refrigeration 31, 1042-1050.

Jones, R.B., Faragher, J.D., Winkler, S., 2006. A review of the influence of postharvest treatments on the quality and glucosinolate content in broccoli (Brassica oleracea var. italica) heads. Postharv Biol. Technol. 41, 1-8.

Keck, A.S., Finley, J.W., 2004. Cruciferous vegetables: cancer protective mechanisms of glucosinolate hydrolysis products and selenium. Integr. Cancer Ther. 3, 5-12.

Koutsoumanis, K., Giannakourou, M., Taoukis, P.S., Nychas, G.J.E., 2002. Application of SLDs (Shelf life Decision system) to marine cultured fish quality. Int. J. Food Microbiol. 73, 375-382.

Lefever, G., Vieville, M., Delage, N., D'Harlingue, A., De Monteclerc, J., Bompeix, G., 2004. Characterization of cell wall enzyme activities, pectin composition, and technological criteria of strawberry cultivars (Fragaria $\mathrm{x}$ ananassa Duch). J. Food Sci. 69, 221-226.

Lisiewska, Z., Kmiecik, W., Slupski, J., 2004. Contents of chlorophylls and carotenoids in frozen dill: effect of usable part and pre-treatment on the content of chlorophylls and carotenoids in frozen dill (Anethum graveolens L.), depending on the time and temperature of storage. Food Chem. 84, 511-518.

Lund, D.B., 1983. Considerations in modelling food processes. Food Technol. 37, 92-94.

Martins, R.C., Silva, C.L.M., 2002. Modelling colour and chlorophyll losses of frozen green beans (Phaseolus vulgaris, L.). Int. J. Refrigeration 25, 966-974.

Martins, R.C., Silva, C.L.M., 2003. Kinetics of frozen stored green beans (Phaseolus vulgaris, L.) quality changes: texture, vitamin C, reducing sugars and starch. J. Food Sci. 68, 1-9.

Martins, R.C., Silva, C.L.M., 2004a. Frozen green beans (Phaseolus vulgaris, L.) quality profile evaluation during home storage. J. Food Eng. 64, 481-488.

Martins, R.C., Silva, C.L.M., 2004b. Computational design of accelerated life testing applied to frozen green beans. J. Food Eng. 64, 455-464.

Martins, R.C., Lopes, I.C., Silva, C.L.M., 2005. Accelerated life testing of frozen green beans (Phaseolus vulgaris L.) quality loss kinetics: colour and starch. J. Food Eng. 67, 339-346.

Martins, R.C., Lopes, V.V., Vicente, A.A., Teixeira, J.A., 2008. Computational shelf-life dating: complex systems approaches to food quality and safety. Food Bioprocess Technol. 1, 207-222.

Nelder, J.A., Mead, R., 1965. A simplex method for function minimization. Comput. J. 7, 308-313.

Nielsen, G.S., Larsen, L.M., Poll, L., 2003. Formation of aroma compounds and lipoxygenase (EC 1.13.11.12) activity in unblanched leek (Allium ampeloprasum Var. Bulga) slices during long-term frozen storage. J. Agric. Food Chem. 51, 1970-1976.

O'Leary, E., Gormley, T.R., Butler, F., Shilton, N., 2000. The effect of freeze-chilling on the quality of ready-meal components. Lebensm. Wiss. Technol. 33, 217-224.

Olivera, D.F., Viña, S.Z., Marani, C.M., Ferreyra, R.M., Mugridge, A., Chaves, A.R., Mascheroni, R.H., 2008. Effect of blanching on the quality of Brussels sprouts (Brassica oleracea L. gemmifera DC) after frozen storage. J. Food Eng. 84, 148-155.

Phimolsiripol, Y., Siripatrawan, U., Tulyathan, V., Cleland, D.J., 2008. Effects of freezing and temperature flutuations during frozen storage on frozen dough and bread quality. J. Food Eng. $84,48-56$.

Pukszta, T., Palich, P., 2007. The effect of freezing conditions of strawberry storage on the level of thawing drip loss. Acta Agrophysica 9, 203-208.

Redmond, G.A., Gormley, T.R., Butler, F., 2004. The effect of shortand long-term freeze-chilling on the quality of cooked green beans and carrots. Innovative Food Sci. Emerg. Technol. 5, $65-72$. 
Reid, D.S., Kotte, K., Kilmartin, P., Young, M., 2003. A new method for accelerated shelf-life prediction for frozen foods. J. Sci. Food Agric. 83, 1018-1021.

Sahari, M.A., Boostani, F.,M., Hamidi, E.,Z., 2004. Effect of low temperature on the ascorbic acid content and quality characteristics of frozen strawberry. Food Chem. 86, 357-363.

Serpen, A., Gökmen, V., Bahçeci, K.S., Acar, J., 2007. Reversible degradation kinetics of vitamin $C$ in peas during frozen storage. Eur. Food Res. Technol. 224, 749-753.

Sikora, E., Cieślik, E., Leszczyńska, T., Filipiak-Florkiewicz, A., Pisulewski, P.M., 2008. The antioxidant activity of selected cruciferous vegetables subjected to aquathermal processing. Food Chem. 107, 55-59.

Simandjuntak, V., Barret, D.M., Wrolstad, R.E., 1996. Cultivar and frozen storage effects on muskmelon (Cucumis melo) colour, texture and cell wall polysaccharide composition. J. Agric. Food Chem. 71, 291-296.

Sousa, M.B., Canet, W., Alvarez, M.D., Tortosa, M.E., 2005. The effect of the pre-treatments and the long and short-term frozen storage on the quality of raspberry (cv. Heritage). Eur. Food Res. Technol. 221, 132-144.
Statasoft, inc., 2007. Statistica (Data Analysis Software System, Version 8.0). www.statsoft.com.

Taoukis, P.S., Fu, B., Labuza, T.P., 1991. Time-temperature indicators. Food Technol. (U.S.) 45, 70-82.

Tsironi, T., Dermesonlouoglou, E., Ginnakourou, M., Taoukis, P., 2009. Shelf life modelling of frozen shrimp at variable temperature conditions. LWT Food Sci. Technol. 42, 664-671.

Van Buggenhout, S., Lille, M., Messagie, I., Van Loey, A., Autio, K., Hendrickx, M., 2006a. Impact of pretreatment and freezing conditions on the microstructure of frozen carrots: qualification and relation to texture loss. Eur. Food Res. Technol. 222, 543-553.

Van Buggenhout, S., Messagie, I., Maes, V., Duvetter, T., Van Loey, A., Hendrickx, M., 2006b. Minimizing texture loss of frozen strawberries: effect of infusion with pectinmethylesterase and calcium combined with different freezing conditions and effect of subsequent storage/thawing conditions. Eur. Food Res. Technol. 223, 395-404.

Weemaes, C.A., Ooms, V., Van Loey, A.M., Hendrickx, M.E., 1999. Kinetics of chlorophyll degradation and colour loss in heated broccoli juice. J. Agric. Food Chem. 47, 2404-2409. 